\title{
Identification of sources of seedling resistance to Phytophthora capsici in Cucumis melo
}

\author{
Nadson de C. Pontes ${ }^{1}$, Frederick M. Aguiar ${ }^{2}$, Leonardo S. Boiteux ${ }^{3}$, Milton L.P. Lima ${ }^{4,5}$, Valter R. Oliveira ${ }^{3}$, \\ Adalberto C. Café Filho ${ }^{4} \&$ Ailton Reis ${ }^{3}$ \\ ${ }^{1}$ Instituto Federal Goiano, Cx. Postal 92, 75650-000, Morrinhos, GO, Brazil; ${ }^{2}$ Departamento de Fitossanidade, Universidade \\ Federal Rural de Pernambuco, 52171-900, Recife, PE, Brazil; Embrapa Hortaliças, Cx. Postal 0218, 70359-970, Brasília, \\ DF, Brazil; ${ }^{4}$ Departamento de Fitopatologia, Universidade de Brasília, 70910-900, Brasilia, DF, Brazil; ${ }^{5}$ Instituto Federal \\ Goiano, Cx. Postal 4457, 75790-000, Urutaí, GO, Brazil
}

Author for correspondence: Ailton Reis, e-mail: ailton.reis@embrapa.br

\begin{abstract}
The employment of genetic resistance to minimize yield losses induced by Phytophthora capsici remains unexplored in melon (Cucumis melo). A diverse collection of melon accessions was evaluated against $P$. capsici isolates at the seedling stage. In the first screening assay, 105 accessions were evaluated using isolate PCpe-04 obtained from cucumber (Cucumis sativus). In a second assay, 31 accessions displaying high levels of resistance in the first assay were challenged with a distinct isolate (PCpe-09 also from cucumber). In a third assay, a subset of 14 selected accessions was re-evaluated using isolates PCpe-09 and PCmo-07 (from strawberry). In the last screening, seven accessions with high levels of resistance across all assays were challenged with five isolates from representative host species [PC-Vagem (snap bean), PCp-129 (Capsicum chinense), PCp-155 (C. annuum), PCpe-09 and PCmo-07] to assess their reaction against a varied sample of $P$. capsici isolates. For two accessions (CNPH-093 and L040), all plants remained free of symptoms after inoculation with all five isolates. Accessions WMR-29, CNPH 084, CNPH 088 and CNPH 092 were also free of symptoms to all isolates, except PCmo-07. These large-spectrum resistance sources might be useful for breeding programs aiming to incorporate resistance against P. capsici in elite melon lines.
\end{abstract}

Key words: disease resistance, genetic breeding, melon, Phytophthora blight.

\section{INTRODUCTION}

Melon (Cucumis melo L.) is an important vegetable crop in many regions around the world (Robinson \& DeckerWalters, 1997; Pitrat, 2008). In Brazil, the climate and soil conditions of the Northeast region in conjunction with improved crop management practices provided the basis for the $>20$-fold increase in melon production observed in the last decades, yielding fruits with high sensorial quality for both domestic and global markets (Santos et al., 2004; Rocha et al., 2010). However, the expansion of the melon area in Brazil as well as its intensive year-round cultivation resulted in an increase in the number of new biotic problems, especially soil-borne diseases (Santos et al., 2004).

The oomycete Phytophthora capsici is one of the main causal agents of the blight and collar rot diseases of melons and other cucurbit crops in Brazil. The effective control of these diseases is difficult due to the wide host range of $P$. capsici and its ability to infect melon plants at different growing stages under both field and post-harvest conditions (Chehri et al., 2010). The currently available chemical and cultural methods to control P. capsici are neither effective nor economically viable (Lamour et al., 2012). The frequent sprays with fungicides increase the risk of environmental contamination as well as the undesirable occurrence of agrochemical residues in the fruit (Liu et al., 2009). In addition, control based upon fungicide applications can exert a selection pressure on the pathogen, favouring the emergence of tolerant populations (Dunn et al., 2010).

The best $P$. capsici control alternative in cucurbits would be the use of resistant cultivars (Gevens et al., 2006). However, the employment of genetic resistance to minimize yield losses induced by $P$. capsici remains largely unexplored in melon. In fact, the majority of the currently grown melon hybrids were found to be susceptible to this pathogen (Ando et al., 2009). There is a very limited number of reports describing extensive searches for sources of resistance to $P$. capsici in melon germplasm. Moreover, breeding for $P$. capsici resistance in distinct pathosystems has been a difficult task due to the complex inheritance of the host reaction, the mechanisms of genetic variability of the pathogen and its broad host range as well as the diverse repertoire of disease effectors present in species of the genus Phytophthora (Bower et al., 2007; Meitz et al., 2010; Oh et al., 2010; Quesada-Ocampo et al., 2011). More recent studies on the genetic structure of global $P$. capsici populations emphasize the importance of expanding the range of isolates in host resistance screening assays to 
better represent the large genetic variation of the pathogen (Quesada-Ocampo et al., 2011). In this scenario, it would be interesting to exploit the available diversity of melon accessions and to search for potential sources of resistance by challenging this germplasm with a wide range of $P$. capsici isolates and environmental conditions. In the present work, we evaluated the reaction of a genetically diverse melon collection to distinct isolates of $P$. capsici, aiming to identify useful sources of broad spectrum resistance for use in breeding programs.

\section{MATERIALS AND METHODS}

\section{Phytophthora capsici isolates and inoculum preparation}

Altogether, six P. capsici isolates from Brazil were employed in four screening assays: PCpe-04 and PCpe-09 (obtained from infected cucumber, C. sativus), PCmo-07 (from strawberry, Fragaria $x$ ananassa), PC-Vagem (from snap bean, Phaseolus vulgaris), PCp-129 (from Capsicum chinense), and PCp-155 (from C. annuum). This range of isolates was chosen for resistance screening assays to estimate the reaction of the accessions to a sample of the large genetic variation of the pathogen (Quesada-Ocampo et al., 2011). Pure cultures of the isolates were transferred to Petri plates containing V8 medium. The cultures were maintained in growth chambers for 10 days $\left(25 \pm 1^{\circ} \mathrm{C}\right.$ under continuous light) to induce abundant sporangia production. After this, $10 \mathrm{~mL}$ of distilled sterilized water were added to each plate. The plates were maintained at $6^{\circ} \mathrm{C}$ for two hours and then at $25^{\circ} \mathrm{C}$ for $30 \mathrm{~min}$, for the production of zoospores. The suspension, containing a high concentration of zoospores, was homogenized by gently manual shaking and then filtered through sterile gauze. One aliquot of the suspension was taken from the flask and heated on fire flame to stop the motility of the zoospores. The zoospore concentration was estimated in a Neubauer's chamber and the final suspension was adjusted to $2 \times 10^{4}$ zoospores $/ \mathrm{mL}$.

\section{Seedling inoculation procedures}

Seeds of the melon accessions were sown in Styrofoam trays with 72 cells, filled with sterile Plantmax ${ }^{\circledR}$ substrate. When the plants had the first pair of true leaves fully open (about 14 days after planting), they were removed from the tray cells and transplanted into plastic pots (five plants into each pot) containing $3 \mathrm{~L}$ of sterile substrate (mix of $100 \mathrm{~L}$ of soil, $100 \mathrm{~L}$ of sand, $300 \mathrm{~g}$ of NPK 4-14-8 fertilizer, $500 \mathrm{~g}$ of lime, $40 \mathrm{~g}$ of ammonium sulphate and 20 $\mathrm{L}$ of burned rice husks). Ten days after transplanting, the plants were inoculated with individual $P$. capsici isolates. Thirty minutes before inoculation the plants were irrigated until water runoff. For pathogen inoculation $3 \mathrm{~mL}$ of the zoospore suspension were placed in the soil around the collar region of each individual plant.

\section{Screening assays}

Four screening assays were carried out under greenhouse conditions at Embrapa Hortaliças (Embrapa
Vegetable Crops), in Brasília, DF, Brazil. In the first assay, 105 C. melo accessions were inoculated with isolate PCpe04. A subset of 31 accessions displaying either resistant or highly resistant reaction to $P$. capsici in first assay plus the three Brazilian field susceptible cultivars ('Eldorado 300', 'Caipira', and 'Gaúcho') were evaluated for their reaction to the PCpe-09 isolate. Only accessions displaying high levels of resistance (no wilt symptoms and absence of stem browning) were selected for the third and fourth assays. In these assays we included the accession CNPH 093, detected as being highly resistance to $P$. capsici isolates in other previous assays (Paz-Lima, 2006), and five advanced melon breeding lines (L001, L022, L040, L091, and L610). In the third assay plants were inoculated with two $P$. capsici isolates (PCpe-09 and PCmo-07). In the fourth assay the same subset of accessions used in the third assay was evaluated against five isolates (PCpe-09, PCmo-07, PCVagem, PCp-129, and PCp-155). The experimental design in the first screening assay was completely randomized with two replications. In the second, third and fourth assays the experimental design was in randomized blocks with three (second and third assay) and four (fourth assay) replications. Each replication was represented by one pot $(3 \mathrm{~L}$ of substrate) with five plants. In all assays, the pathogenicity of the isolates and the inoculum viability was confirmed by simultaneous inoculation of ten sweet pepper (C. annuиm cv. Ikeda) and tomato (Solanum lycopersicum L. cultivar Santa Clara) plants.

\section{Evaluation criteria and data analysis}

In the first assay, the disease incidence [DI (\%)], i.e. the number of plants with typical crown-rot and blight symptoms at 20 days after inoculation, as a proportion of the total number of inoculated plants, was employed as the evaluation criterion. The accessions were arbitrarily classified into six reaction groups according to their DI: 0 $=$ highly resistant (HR); 0.1 to $12.5=$ resistant $(\mathrm{R}) ; 12.6$ to $25=$ moderately resistant (MR); 25.1 to $50=$ moderately susceptible (MS); 50.1 to $75=$ susceptible $(\mathrm{S}) ;>75=$ highly susceptible (HS). For the subsequent three assays, the evaluation criteria were the incubation period (IP), the disease incidence at 20 days after inoculation (DI) and the area under the disease progress curve (AUDPC), calculated with the data of 20 disease incidence evaluations. Spearman's correlation coefficients among the evaluation criteria in each assay were calculated using the procedure (PROC) CORR, as implemented in SAS/STAT guide for personal computers (v. 6; SAS Institute). Clustering analysis (similarity measure of the Standard Euclidian distance) was conducted using the Minitab 14 statistical program to select a subset of accessions comprising the most resistant ones in each assay. In the third and fourth assays the data were also subjected to a nonparametric analysis of variance as described (Akritas et al., 1997) to verify the significance of the effects of the pathogen isolates and the melon accessions as well as the interactions among them, using the procedures 
MIXED and RANK, as implemented in SAS/STAT v. 6. The average values of each evaluation criterion were compared by Fisher's test (LSD) using transformed ("ranks") values with the procedures RANK and GLM (SAS v. 6).

\section{RESULTS AND DISCUSSION}

A broad array of reactions to the $P$. capsici isolate PCpe-04 was observed among the 105 melon accessions in the first assay, ranging from highly resistant (with all plants free of symptoms) to highly susceptible (Table 1). Twenty-one accessions were classified as highly resistant (HR), displaying no blighted plants, whereas 22 accessions were classified as resistant (R). These results indicated that potentially useful sources of resistance to this isolate are available in this germplasm collection.

A subset of 31 accessions (with HR, R and MR responses to $P$. capsici in the first assay) plus three commercial cultivars ('Eldorado 300', 'Caipira', and 'Gaúcho') were evaluated for their reaction to a distinct isolate (PCpe-09). In this second screening assay, 18 accessions displayed a variable number of plants with symptoms, including the three commercial cultivars. Sixteen accessions displayed a highly resistant response to PCpe-09 isolate with all plants free of symptoms (Table 2 ). These results indicated that the HR reaction in the pathosystem melon/P. capsici is more likely to be isolatespecific. Another explanation for the higher percentage of infected plants in the second assay when compared with the reaction of the same accessions in the first assay could be attributed to differences between the two $P$. capsici isolates in relation to their level of aggressiveness. The high number of accessions with susceptible reaction indentified in the two assays corroborates previous results obtained in screening germplasm collections of melon and other cucurbit hosts (Henz \& Lima,1998; Tian \& Babadoost, 2004). In those previous works, $C$. melo cultivars were among the most susceptible hosts to $P$. capsici within samples of several cucurbit species. In our work, however, 16 accessions (CNPH 013, B63.3, HML 1, Aroma 1, PI 180283, Chilton S, WMR 29, CNPH 081, CNPH 082, CNPH 084, CNPH 085, CNPH 088, CNPH 092, Swan, PI 161375, and W6 Selection) did not display any plants with disease symptoms during the entire evaluation time (20 days), indicating the potential presence of sources with large resistance spectrum (Table 2). These accessions were allocated in the same group after clustering analysis (data not shown) and were selected for a new round of evaluation.

In the third assay, the subgroup of 12 selected accessions, five inbred lines and six additional accessions were challenged with the PCpe-09 isolate and with a phenotypically diverse isolate obtained from strawberry plants (PCmo-07). The accessions CNPH 013, PI 180223, CNPH 081, CNPH 082, CNPH 084, CNPH 085, CNPH 088, CNPH 092, and PI 161375 displayed once more high levels of resistance to the PCpe-09 isolate with all plants free of symptoms (Table 3). However, the accessions 'Chilton S' and 'W6 Selection' did not confirm their previous responses, displaying 50 and $36 \%$ of infected plants, respectively. The presence of susceptible plants to the PCpe-09 isolate in these two accessions can be explained by environmental factors interfering with the infection process and disease development (Granke \& Hausbeck, 2010). The average temperature observed during the first, second and third assays were $23.2^{\circ} \mathrm{C}, 24.7^{\circ} \mathrm{C}$ and $26.7^{\circ} \mathrm{C}$, respectively. Therefore, the third assay was conducted under higher temperature, which could provide more favourable environmental conditions to disease onset and development in some of the accessions identified as having a highly resistance response to this isolate in the former assays. The disease incidence for the PCmo-07 isolate in the accessions ranged from $16.6 \%$ to $100 \%$. Statistical differences were detected among the reaction of the accessions against the PCmo-07 isolate, with WMR-29 and CNPH 088 displaying the lowest number of symptomatic plants. The inbred lines L040, L091, and L610 as well as the accessions Chilton S, Diamex, and W6 selection displayed a variable number of susceptible plants to both isolates. Table 3 shows the differences in levels of resistance among accessions for each isolate as well as differences in aggressiveness of the isolates for each accession. The analysis of variance showed an interaction $\left(x^{2} ; \mathrm{P} \leq 0.05\right)$ among isolates and accessions that can be a result of the large number of accessions that did not present disease symptoms when inoculated with isolate PCpe-09. The effect of the isolates was detected in only seven accessions (LSD; $\mathrm{P} \leq 0.05$ ). The isolate PCmo07 had an overall more aggressive behaviour than PCpe09. In all three assays, all epidemiological variables used as evaluation criteria (IP, DI, and AUDPC) presented high levels of correlation. For this reason, only DI values were taken for variance analysis and employed for comparison of the accessions. WMR-29 and CNPH 088 were the two most promising accessions since they showed the lower levels of disease incidence for the isolate PCmo-07 (16.6\%) and presented all plants free of symptoms when inoculated with the PCpe-09 isolate (Table 3). Seven accessions (L040, WMR-29, CNPH 081, CNPH 084, CNPH 088, CNPH 092, and CNPH 093) clustered in the resistant group in the third assay (data not shown).

The fourth assay was a round of evaluation against an array of five distinct $P$. capsici isolates. The accession Diamex was included as a susceptible standard. All plants of the accession CNPH 093 and the inbred line L040 were free of symptoms to all five isolates. The accessions WMR29, CNPH 084, CNPH 088, and CNPH 092 also displayed similar, immunity-like reaction to all isolates except PCmo07. In this fourth assay, variance analysis using DI values showed significant interaction among melon accessions and pathogen isolates $\left(x^{2} ; \mathrm{P} \leq 0,05\right)$. The isolate $\mathrm{PCmo}-07$ was able to cause collar rot in six out of eight accessions. On the other hand, no melon accession was found to be susceptible to the three P. capsici isolates (PC-Vagem, PCp-129, and 
TABLE 1 - Crown rot incidence and groups of reaction after screening 105 melon (Cucumis melo) accessions at the seedling stage for resistance against the Phytophthora capsici isolate PCpe-04 (obtained from infected cucumber plants).

\begin{tabular}{|c|c|c|c|c|c|}
\hline Accession, line or cultivar & $\begin{array}{c}\text { Disease } \\
\text { Incidence (\%) }\end{array}$ & $\begin{array}{c}\text { Reaction } \\
\text { group* }\end{array}$ & Accession, line or cultivar & $\begin{array}{c}\text { Disease } \\
\text { Incidence }(\%)\end{array}$ & $\begin{array}{c}\text { Reaction } \\
\text { group }\end{array}$ \\
\hline Perlita Selection 1 & 100 & HS & Charentais Hollar Co. & 25 & MR \\
\hline Rondo & 100 & HS & B66.5-1 & 25 & MR \\
\hline Perlita Bush S2 & 100 & HS & AS 200234 & 25 & MR \\
\hline Perlita Selection 2 & 100 & HS & Pancha F1 & 25 & MR \\
\hline Herm Line & 100 & HS & Charentais FOM1-1 & 25 & MR \\
\hline Rondo S & 100 & HS & PI 164433 & 25 & MR \\
\hline Taiwan \# 7 & 100 & HS & Melão Verdadeiro & 25 & MR \\
\hline Hales Best Jumbo & 100 & HS & Gaucho St Angelo 1/RS & 25 & MR \\
\hline Cinco & 100 & HS & Gaucho St Angelo 2/RS & 25 & MR \\
\hline WI998E & 100 & HS & TM 002 F1 & 25 & MR \\
\hline Cinco Selection & 100 & HS & Gulf Coast & 12.5 & $\mathrm{R}$ \\
\hline Edisto 47 & 87.5 & HS & Amarelo Horticeres & 12.5 & $\mathrm{R}$ \\
\hline Line HML-1 & 87.5 & HS & B63.3 INRA & 12.5 & $\mathrm{R}$ \\
\hline Mainstream & 75 & $\mathrm{~S}$ & HML-1 & 12.5 & $\mathrm{R}$ \\
\hline Melão Pepino & 75 & $\mathrm{~S}$ & Aroma \#1 & 12.5 & $\mathrm{R}$ \\
\hline W6 S1 & 75 & $\mathrm{~S}$ & Edisto $47 \mathrm{~S} 1$ & 12.5 & $\mathrm{R}$ \\
\hline Rondo & 75 & $\mathrm{~S}$ & Taiwan Test Cross & 12.5 & $\mathrm{R}$ \\
\hline Charentais-IPB Seeds & 75 & $\mathrm{~S}$ & PI 161375-1 & 12.5 & $\mathrm{R}$ \\
\hline Hales Best Jumbo-1 & 75 & $\mathrm{~S}$ & CNPH-086 & 12.5 & $\mathrm{R}$ \\
\hline Super Sprint & 75 & $\mathrm{~S}$ & CNPH-087 & 12.5 & $\mathrm{R}$ \\
\hline Super Market & 62.5 & $\mathrm{~S}$ & CNPH-093 & 12.5 & $\mathrm{R}$ \\
\hline Chaca No. 1 & 62.5 & $\mathrm{~S}$ & Golden Beauty & 12.5 & $\mathrm{R}$ \\
\hline CNPH-094 & 62.5 & $\mathrm{~S}$ & Swan & 12.5 & $\mathrm{R}$ \\
\hline Gynox Line & 50 & MS & Isoline T FOM1 & 12.5 & $\mathrm{R}$ \\
\hline GRP S1 & 50 & MS & Green Ice & 12.5 & $\mathrm{R}$ \\
\hline Golf Coast & 50 & MS & Diamex & 12.5 & $\mathrm{R}$ \\
\hline Valencia & 50 & MS & Douradinho da China & 12.5 & $\mathrm{R}$ \\
\hline Amarelo $x$ Chilton & 50 & MS & CNPH-303 & 12.5 & $\mathrm{R}$ \\
\hline W998E x Gyno & 50 & MS & CNPH-304 & 12.5 & $\mathrm{R}$ \\
\hline CNPH-090 & 50 & MS & Helios & 12.5 & $\mathrm{R}$ \\
\hline Charentais $\mathrm{T}$ & 50 & MS & Glaver & 12.5 & $\mathrm{R}$ \\
\hline PI 414723 & 50 & MS & Netted Melon & 12.5 & $\mathrm{R}$ \\
\hline BRA - 000621 & 50 & MS & Belle Vine Green 1 & 0 & HR \\
\hline Pharo F1 & 50 & MS & Aroma \#2 & 0 & HR \\
\hline Valencia & 50 & MS & VC Perlita Bush S1 & 0 & HR \\
\hline Charentais FOM2 & 50 & MS & CNPH-013 & 0 & $\mathrm{HR}$ \\
\hline Sea Bolt & 50 & MS & PI 180283 & 0 & HR \\
\hline Prince & 37.5 & MS & Chilton S & 0 & HR \\
\hline Cinco SJ82A30 & 37.5 & MS & Taiwan Test Cross S2 & 0 & HR \\
\hline Top Mark & 37.5 & MS & Napolitano & 0 & HR \\
\hline CNPH-095 & 37.5 & MS & CNPH-081 & 0 & HR \\
\hline CNPH-097 & 37.5 & MS & CNPH-082 & 0 & HR \\
\hline Golden Charm & 37.5 & MS & CNPH-084 & 0 & HR \\
\hline Charentais FOM1 & 37.5 & MS & CNPH-085 & 0 & HR \\
\hline B633-3 & 37.5 & MS & CNPH-088 & 0 & HR \\
\hline Rockmelon Gulfcoast & 37.5 & MS & CNPH-089 & 0 & HR \\
\hline Ananas & 37.5 & MS & CNPH-092 & 0 & HR \\
\hline CNPH-008 & 25 & MR & CNPH-096 & 0 & HR \\
\hline Chilton & 25 & MR & Farmer's Yellow no.2 & 0 & HR \\
\hline Hales Best Jumbo-2 & 25 & MR & PI $161375-2$ & 0 & HR \\
\hline В 66.5 & 25 & MR & Muskmelon 18072 & 0 & HR \\
\hline \multirow[t]{2}{*}{ WMR-29 } & 25 & MR & H019 & 0 & HR \\
\hline & & & W6 (Selection) & 0 & HR \\
\hline
\end{tabular}

*No blighted plants $(0 \%$ incidence $)=$ highly resistant $(\mathrm{HR}) ; 0.1$ to $12.5 \%=$ resistant $(\mathrm{R}) ; 12.6 \%$ to $26 \%=$ moderately resistant $(\mathrm{MR}) ; 26.1 \%$ to $50 \%=$ moderately susceptible (MS); 50.1 to $75 \%=$ susceptible (S); and 75.1 to $100 \%$ of blighted plants $=$ highly susceptible (HS). 
N.C. Pontes et al.

TABLE 2 - Average values for disease incidence (DI, 20 days after inoculation), incubation period (IP) and area under the disease curve progress (AUDPC) for 34 melon (Cucumis melo) accessions evaluated for their reaction against the Phytopthora capsici isolate PCpe-09 (obtained from infected Cucumis sativus plants).

\begin{tabular}{|c|c|c|c|c|c|c|c|}
\hline Accessions & DI (\%) & IP (days) & AUDPC & Accessions & DI (\%) & IP (days) & AUDPC \\
\hline Belle Vine Green 1 & 11.10 & 17.00 & 127.65 & CNPH-082 & 0.00 & - & 0.00 \\
\hline Aroma \#2 & 38.33 & 11.56 & 514.17 & CNPH-084 & 0.00 & - & 0.00 \\
\hline VC Perlita Bush & 8.33 & 16.33 & 112.50 & CNPH-085 & 0.00 & - & 0.00 \\
\hline CNPH 008 & 26.67 & 19.33 & 53.33 & CNPH-087 & 20.00 & 18.17 & 70.00 \\
\hline Gulf Coast & 33.33 & 15.56 & 236.67 & CNPH-088 & 0.00 & - & 0.00 \\
\hline Chilton & 21.67 & 11.17 & 307.50 & CNPH-089 & 6.67 & 16.33 & 90.00 \\
\hline CNPH-013 & 0.00 & - & 0.00 & CNPH-092 & 0.00 & - & 0.00 \\
\hline H. Best Jumbo 2 & 40.00 & 14.67 & 360.00 & CNPH-094 & 13.33 & 16.00 & 93.33 \\
\hline B63.3 INRA & 0.00 & - & 0.00 & Swan & 0.00 & - & 0.00 \\
\hline PI 180283 & 0.00 & - & 0.00 & PI 161375 & 0.00 & - & 0.00 \\
\hline HML-1 & 0.00 & - & 0.00 & Musk.18072 & 6.67 & 18.67 & 43.33 \\
\hline Aroma \#1 & 0.00 & - & 0.00 & Н 019 & 28.87 & 15.00 & 275.86 \\
\hline Chilton S & 0.00 & - & 0.00 & Diamex & 93.33 & 7.85 & 1180.00 \\
\hline WMR-29 & 0.00 & - & 0.00 & W6 Selection & 0.00 & - & 0.00 \\
\hline Taiwan TC & 26.67 & 11.00 & 386.67 & Eldorado & 6.67 & 19.67 & 23.33 \\
\hline Napolitano & 8.33 & 16.00 & 120.83 & Caipira & 13.33 & 19.83 & 40.00 \\
\hline CNPH-081 & 0.00 & - & 0.00 & Gaúcho & 6.67 & 19.67 & 23.33 \\
\hline
\end{tabular}

TABLE 3 - Average value of disease incidence (DI, 20 days after inoculation) for 23 melon (Cucumis melo) accessions inoculated with the Phytopthora capsici isolates PCmo-07 (obtained from strawberry) and PCpe-09 (obtained from infected cucumber plants).

\begin{tabular}{|c|c|c|}
\hline \multirow[b]{2}{*}{ Accessions } & \multicolumn{2}{|c|}{ Isolates } \\
\hline & $\begin{array}{l}\text { DI } \\
\text { PCmo-07 }\end{array}$ & $\begin{array}{l}\text { DI } \\
\text { PCpe-09 }\end{array}$ \\
\hline CNPH-013 & $75.0 \mathrm{ABCDE}^{1}$ & $0.0 \mathrm{E} \mathrm{b}$ \\
\hline B63.3 INRA & 66.6 ABCDEF a & $0.0 \mathrm{E} \mathrm{b}$ \\
\hline PI 180283 & 66.6 ABCDEF a & $0.0 \mathrm{E} \mathrm{b}$ \\
\hline HML-1 & $88.9 \mathrm{ABC}$ a & $0.0 \mathrm{E} \mathrm{b}$ \\
\hline Aroma \#1 & $91.6 \mathrm{AB}$ a & $0.0 \mathrm{E} \mathrm{b}$ \\
\hline Chilton S & $100.0 \mathrm{~A} \mathrm{a}$ & $50.0 \mathrm{C} \mathrm{b}$ \\
\hline WMR-29 & $16.6 \mathrm{G} \mathrm{a}$ & $0.0 \mathrm{E} \mathrm{a}$ \\
\hline CNPH-081 & 41.6 DEFG a & $0.0 \mathrm{E} \mathrm{b}$ \\
\hline CNPH-082 & $100.0 \mathrm{~A} \mathrm{a}$ & $0.0 \mathrm{E} \mathrm{b}$ \\
\hline CNPH-084 & 41.6 EFG a & $0.0 \mathrm{E} \mathrm{b}$ \\
\hline CNPH-085 & 66.6 ABCDEF a & $0.0 \mathrm{E} \mathrm{b}$ \\
\hline CNPH-088 & $16.6 \mathrm{G} \mathrm{a}$ & $0.0 \mathrm{E} \mathrm{a}$ \\
\hline CNPH-092 & $50.0 \mathrm{CDEFG} \mathrm{a}$ & $0.0 \mathrm{E} \mathrm{b}$ \\
\hline CNPH-093 & $33.3 \mathrm{FG} \mathrm{a}$ & $0.0 \mathrm{E} \mathrm{a}$ \\
\hline Swan & $100.0 \mathrm{~A} \mathrm{a}$ & $0.0 \mathrm{E} \mathrm{b}$ \\
\hline PI 161375 & $58.3 \mathrm{ABCDEF}$ a & $0.0 \mathrm{E} \mathrm{b}$ \\
\hline W6 Selection & 50.0 BCDEFG a & $36.1 \mathrm{C} \mathrm{a}$ \\
\hline Diamex & 58.3 BCDEF a & $100.0 \mathrm{~A} \mathrm{a}$ \\
\hline L001 & $83.3 \mathrm{ABCD}$ a & $0.0 \mathrm{E} \mathrm{b}$ \\
\hline L022 & $91.6 \mathrm{ABC}$ a & $0.0 \mathrm{E} \mathrm{b}$ \\
\hline L040 & $33.3 \mathrm{FG} \mathrm{a}$ & $8.3 \mathrm{DE} \mathrm{a}$ \\
\hline L091 & $91.6 \mathrm{ABC}$ a & $75.0 \mathrm{~B} \mathrm{a}$ \\
\hline L610 & $91.6 \mathrm{AB}$ a & $8.3 \mathrm{D} \mathrm{b}$ \\
\hline
\end{tabular}

${ }^{1}$ Values followed by the same capital letter in columns and the same lowercase letters in lines are not significantly different according to Fisher's LSD test $(\mathrm{P} \leq 0.05)$.

${ }^{2} \mathrm{CV}$, Coefficient of variation. 
PCp-155) (Table 4). In fact, previous work conducted by Paz-Lima (2006) observed a high number of melon accessions with all plants free of symptoms to a $P$. capsici isolate obtained from Capsicum. Therefore, additional work will be necessary to demonstrate that, in fact, isolates obtained from other hosts (e.g. Capsicum and snap bean) have narrow virulence profiles in alternative hosts such as C. melo. Similarly, the characterization of $P$. capsici isolates from Italy revealed that only $20 \%$ of them were able to cause disease on melon plants (Tamietti \& Valentino, 2001). Taken together, these results indicate the potential presence of isolate-specific reactions in melon accessions, since a subset of $P$. capsici isolates was unable to infect melon accessions that were found to be highly susceptible to other isolates. Therefore, pathogen variability has to be taken into account, as previously indicated (Quesada-Ocampo et al., 2011), when working with the identification of genuine resistance sources of resistance to $P$. capsici isolates of epidemiological importance to melons.

Accessions CNPH 081 and Diamex were the only ones with susceptible plants to isolate PCpe-09 in the fourth assay. However, only Diamex was statistically distinct from the other seven accessions for DI (LSD; $\leq 0,05$ ). The accessions WMR29, CNPH 093, and L040 had the highest resistance levels to PCmo-07, differing from the other accessions (Table 4). The accession CNPH 088 did not confirm its previous reaction to PCmo-07 (Table 3), displaying more than half of the plants with symptoms. As discussed earlier, changes on environmental conditions might be responsible for might be responsible for instability of the phenotypic response of some accessions to isolates of $P$. capsici. This type of reaction suggests the need to carry out different melon germplasm screening assays under distinct environmental conditions.

The $P$. capsici isolates studied here displayed differences in host range and levels of aggressiveness to melon. Variability in the host range of $P$. capsici isolates has been previously reported among Capsicum and among distinct cucurbit species (Foster \& Hausbeck, 2010). Some studies have indicated the existence of physiological races in the Capsicum-P. capsici pathosystem (Glosier et al., 2008; Sy et al., 2008). No melon accession evaluated here reacted as being entirely free of symptoms to all isolates in all assays, suggesting the potential presence of isolatespecific interactions in the $P$. capsici-melon pathosystem. This fact reinforces the need for evaluating melon germplasm with more than one isolate, and these isolates should preferentially come from different hosts and geographical regions in order to increase the chances of obtaining breeding materials with large-spectrum resistance (Meitz et al., 2010).

So far there are few reports of sources resistance to $P$. capsici at the seedling stage in cucurbit hosts. Evaluations have been restricted to Cucurbita moschata (Henz \& Lima, 1998; Chavez et al., 2011) and C. pepo (Padley Jr. et al., 2008) germplasm. In those works, the number of highly resistant accessions was generally low and the identification of accessions with highly resistance response was rare. A similar scenario of complete absence of sources with high levels of resistance was observed in relation to $P$. capsici fruit rot after evaluation carried out with 300 cucurbit accessions (Hausbeck \& Lamour, 2004). However, the lesion area in fruits of some accessions was limited and/or the sporulation of pathogen was significantly reduced. In this context, the identification of sources with high levels of seedling resistance in melon germplasm to a range of isolates is an important finding from the breeding standpoint. It is well reported in other P. capsici pathosystems that host resistance increases with plant age (Reifschneider et al., 1992; Ando et al., 2009) and even susceptible cultivars might withstand the pathogen's attack when the inoculation is performed in older plants (Henz \& Lima, 1998). Therefore, the fact that the isolate-specific resistance in melon accessions is expressed at the juvenile (seedling) stage is another important finding of our work.

TABLE 4 - Average value of disease incidence (DI) for eight melon (Cucumis melo) accessions inoculated with the Phytopthora capsici isolates PCpe-09, PCmo-07, PC-Vagem, PCp-129, and PCp-155.

\begin{tabular}{|c|c|c|c|c|c|}
\hline \multirow[b]{2}{*}{ Accessions } & \multicolumn{5}{|c|}{ Isolates } \\
\hline & $\begin{array}{c}\text { DI } \\
\text { PCpe-09 }\end{array}$ & $\begin{array}{c}\text { DI } \\
\text { PCmo-07 }\end{array}$ & $\begin{array}{c}\text { DI } \\
\text { PC-Vagem }\end{array}$ & $\begin{array}{c}\text { DI } \\
\text { PCp-129 }\end{array}$ & $\begin{array}{c}\text { DI } \\
\text { PCp-155 }\end{array}$ \\
\hline WMR-29 & $0.0 \mathrm{~A} \mathrm{a}^{1}$ & $6.2 \mathrm{AB}$ a & $0.0 \mathrm{~A} \mathrm{a}$ & $0.0 \mathrm{~A} \mathrm{a}$ & $0.0 \mathrm{~A} \mathrm{a}$ \\
\hline CNPH 081 & $6.25 \mathrm{~A} \mathrm{a}$ & $50.0 \mathrm{D} \mathrm{b}$ & $0.0 \mathrm{~A} \mathrm{a}$ & $0.0 \mathrm{~A} \mathrm{a}$ & $0.0 \mathrm{~A} \mathrm{a}$ \\
\hline CNPH 084 & $0.0 \mathrm{~A} \mathrm{a}$ & $47.9 \mathrm{CD} \mathrm{b}$ & $0.0 \mathrm{~A} \mathrm{a}$ & $0.0 \mathrm{~A} \mathrm{a}$ & $0.0 \mathrm{~A} \mathrm{a}$ \\
\hline CNPH 088 & $0.0 \mathrm{~A} \mathrm{a}$ & $56.2 \mathrm{D} \mathrm{b}$ & $0.0 \mathrm{~A} \mathrm{a}$ & $0.0 \mathrm{~A} \mathrm{a}$ & $0.0 \mathrm{~A} \mathrm{a}$ \\
\hline CNPH 092 & $0.0 \mathrm{~A} \mathrm{a}$ & $31.2 \mathrm{D} \mathrm{b}$ & $0.0 \mathrm{~A} \mathrm{a}$ & $0.0 \mathrm{~A} \mathrm{a}$ & $0.0 \mathrm{~A} \mathrm{a}$ \\
\hline CNPH 093 & $0.0 \mathrm{~A} \mathrm{a}$ & $0.0 \mathrm{~A} \mathrm{a}$ & $0.0 \mathrm{~A} \mathrm{a}$ & $0.0 \mathrm{~A} \mathrm{a}$ & $0.0 \mathrm{~A} \mathrm{a}$ \\
\hline L040 & $0.0 \mathrm{~A} \mathrm{a}$ & $0.0 \mathrm{~A} \mathrm{a}$ & $0.0 \mathrm{~A} \mathrm{a}$ & $0.0 \mathrm{~A} \mathrm{a}$ & $0.0 \mathrm{~A} \mathrm{a}$ \\
\hline Diamex & $62.5 \mathrm{~B} \mathrm{a}$ & $12.5 \mathrm{BC} \mathrm{b}$ & $0.0 \mathrm{~A} \mathrm{c}$ & $0.0 \mathrm{~A} \mathrm{c}$ & $0.0 \mathrm{Ac}$ \\
\hline $\mathrm{CV}(\%)^{2}$ & \multicolumn{5}{|c|}{15.51} \\
\hline
\end{tabular}

${ }^{1}$ Values followed by the same capital letter in columns and the same lowercase letters in lines are not significantly different according to Fisher's LSD test $(\mathrm{P} \leq 0.05)$.

${ }^{2} \mathrm{CV}=$ Coefficient of variation. 
There are several examples of isolate-specific resistance governed by major, simply-inherited genetic factors in breeding for resistance to Phytophthora species in distinct hosts (van de Weg, 1997; Tyler, 2002; MonroyBarbosa \& Bosland, 2008; Nowicki et al., 2012). Therefore, inheritance studies with these selected sources and these isolates are the next logical step aiming to clarify the genetic control of this trait in melon. However, the potential confirmation of distinct races in melon will be a complicating factor (Oelke et al., 2003). In this case, even with the availability of major isolate-specific resistance genes, it will be advisable to characterize sources of quantitative and/or partial resistance since this type of resistance is usually more effective and durable against a wide range of pathogen isolates and environmental conditions (Hausbeck \& Lamour, 2004; Foster \& Hausbeck, 2010). In Capsicum, for example, there are different genes that confer partial (quantitative) resistance against $P$. capsici with a wide spectrum of efficiency (Quirin et al., 2005; Minamiyama et al., 2007; Glosier et al.. 2008; Sy et al., 2008). Quantitative resistance to $P$. capsici isolates has been also detected in $C$. moschata and wild Cucurbita species (Kabelka et al., 2007; Padley Jr. et al., 2009).

The best $P$. capsici control alternative in melon would be the use of resistant cultivars (Gevens et al., 2006). However, the majority of the currently grown melon hybrids and cultivars is susceptible to this pathogen (Henz \& Lima, 1998; Ando et al., 2009). This group of melon accessions with seedling resistance represents an important genetic resource aiming to advance the breeding for $P$. capsici resistance in this vegetable crop.

\section{ACKNOWLEDGMENTS}

The first and second authors would like to express their gratitude to Fundação de Amparo à Pesquisa do Estado de Minas Gerais - FAPEMIG and Conselho Nacional de Desenvolvimento Científico e Tecnológico - CNPq for their D.Sc. and M.Sc. fellowships, respectively. Leonardo S. Boiteux, Adalberto C. Café Filho and Ailton Reis would like to thank CNPq for their reasearch fellowships.

\section{REFERENCES}

Akritas MG, Arnold SF, Brunner E (1997) Nonparametric hypothesis and rank statistics for unbalanced factorial designs. Journal of the American Statistical Association 92:258-265.

Ando K, Hammar S, Grumet R (2009) Age-related resistance of diverse cucurbit fruit to infection by Phytophthora capsici. Journal of the American Society for Horticultural Science 134:176-182.

Bowers JH, Martin FN, Tooley PW, Luz EDMN (2007) Genetic and morphological diversity of temperate and tropical isolates of Phytophthora capsici. Phytopathology 97:492-503.

Chavez DJ, Kebelka EA, Chaparro JX (2011) Screening of Cucurbita moschata Duchesne germplasm for crown rot resistance to Floridian isolates of Phytophthora capsici Leonian. HortScience 46:536-540.

Chehri K, Abbasi S, Reddy KRN, Salleh B (2010) Occurrence and pathogenicity of various pathogenic fungi on cucurbits from Kermanshah province, Iran. African Journal of Microbiology Research 4:1215-1223.

Dunn AR, Milgroom MG, Meitz JC, McLeod A, Fry WE, McGrath MT, Dillard HR, Smart CD (2010) Population structure and resistance to Mefenoxam of Phytophthora capsici in New York State. Plant Disease 94:1461-1468.

Foster JM, Hausbeck MK (2010) Resistance of pepper to Phytophthora crown, root, and fruit rot is affected by isolate virulence. Plant Disease 94:24-30.

Gevens AJ, Ando K, Lamour KH, Grumet R, Hausbeck MK (2006) A detached cucumber fruit method to screen for resistance to Phytophthora capsici and effect of fruit age on susceptibility to infection. Plant Disease 90:1276-1282.

Glosier BR, Ogundiwin EA, Sidhu GS, Sischo DR, Prince JP (2008) A differential series of pepper (Capsicum annuum) lines delineates fourteen physiological races of Phytophthora capsici. Euphytica 162: 23-30.

Granke LL, Hausbeck MK (2010) Effects of temperature, humidity, and wounding on development of Phytophthora rot of cucumber fruit. Plant Disease 94:1417-1424.

Hausbeck MK, Lamour KH (2004) Phytophthora capsici on vegetable crops: Research progress and management challenges. Plant Disease 88: 1292-1303.

Henz GP, Lima MF (1998) Resistência de plântulas de cultivares de cucurbitáceas ao tombamento causado por Phytophthora capsici. Pesquisa Agropecuária Brasileira 33:853-859.

Kabelka E, Padley L, Roberts P, Ramos L, Martinez M, Klassen W (2007) Resistance to Phytophthora capsici within winter squash (Cucurbita moschata) derived from a wild Cucurbita species. HortScience 42:1014-1014.

Lamour KH, Stam R, Jupe J, Huitema E (2012) The oomycete broad-host-range pathogen Phytophthora capsici. Molecular Plant Pathology 13:329-337.

Liu D, Qin DM, Ji R (2009) Dissipation of mefenoxam residue in watermelon and soil under field conditions. Bulletin of Environmental Contamination and Toxicology 84:230-235.

Meitz JC, Linde CC, Thompson A, Langenhoven S, McLeod A (2010) Phytophthora capsici on vegetable hosts in South Africa: Distribution, host range and genetic diversity. Australasian Plant Pathology 39:431-439.

Minamiyama Y, Tsuro M, Kubo T, Hirai M (2007) QTL analysis for resistance to Phytophthora capsici in pepper using a high density SSR-based map. Breeding Science 57:129-134.

Monroy-Barbosa A, Bosland PW (2008) Genetic analysis of Phytophthora root rot race-specific resistance in chili pepper. Journal of the American Society for Horticultural Science 133:825-829.

Nowicki M, Foolad MR, Marzena N, Kozik EU (2012) Potato and tomato late blight caused by Phytophthora infestans: An overview of pathology and resistance breeding. Plant Disease 96:4-17.

Oelke LM, Bosland PW, Steiner R (2003) Differentiation of race specific resistance to Phytophthora root rot and foliar blight 
in Capsicum annuum. Journal of the American Society for Horticultural Science 128:213-218.

Oh SK, Kamoun S, Choi D (2010) Oomycetes RXLR effectors function as both activator and suppressor of plant immunity. Plant Pathology Journal 26:209-215.

Padley Jr LD, Kabelka EA, Roberts PD, French R (2008) Evaluation of Cucurbita pepo accessions for crown rot resistance to isolates of Phytophthora capsici. Hortscience 43:1996-1999.

Padley Jr LD, Kabelka EA, Roberts PD (2009) Inheritance of resistance to crown rot caused by Phytophthora capsici in Cucurbita. Hortscience 44:211-213.

Paz-Lima ML (2006) Caracterização fenotípica e molecular de Phytophthora capsici de hortaliças e expressão e prospecção da resistência em Cucurbitaceae e Solanaceae. D.Sc. Thesis, Universidade de Brasília. Brasília DF, Brazil.

Pitrat M (2008) Melon (Cucumis melo L.). In: Prohens J, Nuez F (Eds.) Handbook of Crop Breeding. Vol I. Vegetables. New York NY, USA. Springer.

Quesada-Ocampo LM, Granke LL, Mercier MR, Olsen J, Hausbeck MK (2011) Investigating the genetic structure of Phytophthora capsici populations. Phytopathology 101:1061-1073.

Quirin EA, Ogundiwin EA, Prince JP, Mazourek M, Briggs MO, Chlanda TS, Kim KT, Falise M, Kang BC, Jahn MM (2005) Development of sequence characterized amplified region (SCAR) primers for the detection of Phyto.5.2, a major QTL for resistance to Phytophthora capsici Leon. in pepper. Theoretical and Applied Genetics 110:605-612.
Reifschneider FJB, Boiteux LS, Della-Vecchia PT, Poulos JM, Kuroda N (1992) Inheritance of adult-plant resistance to Phytophthora capsici in pepper. Euphytica 62:45-49.

Robinson RW, Decker-Walters DS (1997) Cucurbits. Wallingford UK. CAB International.

Rocha RHC, Silva EO, Salomão LCC, Ventrella MC (2010) Caracterização morfoanatômica do melão gália no ponto de colheita. Revista Brasileira de Fruticultura 32:375-385.

Santos AA, Crisóstomo JR, Cardoso JW (2004) Avaliação de híbridos de melão quanto às principais doenças nos Estados do Ceará e Rio Grande do Norte (Boletim de Pesquisa e Desenvolvimento 16). Fortaleza CE, Brazil. Embrapa Agroindústria Tropical.

Sy O, Steiner R, Bosland PW (2008) Recombinant inbred line differential identifies race-specific resistance to Phytophthora root rot in Capsicum annuum. Phytopathology 98:867-870.

Tamietti G, Valentino D (2001) Physiological characterisation of a population of Phytophthora capsici Leon. from Northern Italy. Journal of Plant Pathology 83:199-205.

Tian D, Babadoost M (2004) Host range of Phytophthora capsici from pumpkin and pathogenicity of isolates. Plant Disease 88:485489.

Tyler BM (2002) Molecular basis of recognition between Phytophthora pathogens and their hosts. Annual Review of Phytopathology 40:137-167.

Van de Weg WE (1997) Resistance to Phytophthora fragariae var. fragariae in strawberry: The Rpf2 gene. Theoretical and Applied Genetics 94:1092-1096. 